\title{
Response of the pearl oyster Pinctada margaritifera to cadmium and chromium: Identification of molecular biomarkers
}

\author{
Gueguen Yannick ${ }^{1,2}$, Saulnier Denis ${ }^{1}$, Santini Adrien ${ }^{1}$, Magre Kevin ${ }^{1}$, Garen Pierre ${ }^{1}$, \\ Bernagout Solène ${ }^{3}$, Nohl Marine ${ }^{3}$, Bouisset Patrick ${ }^{3}$, Helme Herehia ${ }^{3}$, Planes Serge, \\ Le Moullac Gilles ${ }^{1,}$
}

\footnotetext{
1 Ifremer, UMR 241 EIO, UPF-ILM-IRD, Labex Corail, BP 49, 98719 Taravao, Tahiti, French Polynesia

2 Ifremer, UMR 5244 IHPE, UPVD, CNRS, Université de Montpellier, CC 80, F-34095 Montpellier, France

${ }^{3}$ IRSN - LESE, BP 182, 98725 Vairao, Tahiti, French Polynesia

${ }^{4}$ Labex Corail, USR 3278 CNRS-CRIOBE- EPHE, Perpignan, France, Papetoai, Moorea, French

Polynesia

*Corresponding author : Gilles Le Moullac, email address : gilles.le.moullac@ifremer.fr
}

\begin{abstract}
:
This study was designed to identify in the pearl oyster Pinctada margaritifera, used as a bio-accumulator, molecular biomarkers for the presence of heavy metals in the lagoon environment. Pearl oysters were exposed to 2 concentrations (1 and $10 \mu \mathrm{g} \mathrm{L}-1)$ of cadmium $(\mathrm{Cd})$ and chromium $(\mathrm{Cr})$ compared to a control. Twelve target genes encoding proteins potentially involved in the response to heavy metal contamination with antioxidant, detoxification or apoptosis activities were selected. $P$. margaritifera accumulated $\mathrm{Cd}$ but not $\mathrm{Cr}$, and mortality was related to the amount of $\mathrm{Cd}$ accumulated in tissues. In response to $\mathrm{Cd}$-Cr contamination, metallothionein (MT) was significantly up-regulated by $\mathrm{Cd}-\mathrm{Cr}$ at both concentrations, while 7 others (SOD, CAT, GPX, GSTO, GSTM, CASP, MDR) were down-regulated. Based on the development of these molecular tools, we propose that the pearl oyster, $P$. margaritifera, could be used as a sentinel species for heavy metal contamination in the lagoons of tropical ecosystems.
\end{abstract}

\section{Highlights}

- The pearl oyster Pinctada margaritifera accumulated cadmium. Metallothionein gene expression was significantly up-regulated by cadmium. $>$. margaritifera could be a sentinel species of the heavy metals contamination.

Keywords: Pinctada margaritifera, French Polynesia, Cadmium, Chromium, Gene expression, Metallothionein 
Heavy metal contamination in coastal and marine environments has become an increasingly serious threat to both naturally stressed marine ecosystems and human societies that rely on marine resources for food, industry and recreation. Heavy metals contribute to the degradation of marine ecosystems not only by reducing species diversity and abundance but also through their accumulation and persistence in living organisms, even throughout the food chain (Hosono et al., 2011). They are introduced into coastal and marine environments via a variety of sources, including industry, wastewater and domestic effluent (Fu and Wang, 2011). Biomonitoring of the environment and assessment of ecosystem health play essential roles in developing effective strategies for environmental protection, human health and sustainable development.

The use of biological responses to contaminant exposure by sentinel species has become a useful tool in environmental quality evaluation and risk assessment. Among the numerous ecotoxicological 
biomarkers proposed in recent decades, those based on responses at the molecular and cellular levels usually provide the earliest signals of environmental disturbance and are commonly used for biomonitoring (Moore et al., 2004; Viarengo et al., 2007). Detecting the presence of heavy metals in the water column or in the sediment is challenging because of their low concentrations and their transient presence. However, many organisms have the potential to absorb heavy metals from ambient waters and retain them in their tissues, sometimes leading to extremely high concentrations. Because of the widely different environments that they inhabit, and their ability to accumulate heavy metals in their tissues, bivalves such as mussels, oysters and pearl oysters have been extensively utilised as bioindicators in environmental toxicology (Sidoumou et al., 2005; Viarengo et al., 2007; Maanan, 2008; Giarratano et al., 2010;Nazer, 2013; Taylor et al., 2013; Izagirre et al., 2014). These bivalves are sessile and filter-feeding organisms and can be considered sentinel organisms for pollution-monitoring studies.

Coral reef ecosystems in French Polynesia are considered to be healthy overall (Salvat et al., 2008), but increasing anthropogenic activity is significantly impacting some areas, especially near urban centers. In this context, the objective of this study was to evaluate the possibility for the pearl oyster Pinctada margaritifera to be a model sentinel species for characterising the health status of coral ecosystems. As such, P. margaritifera pearl oysters were exposed to cadmium and chromium at different concentrations within a controlled environment in order to (i) evaluate the mortality rate under varying concentrations and (ii) analyse the oysters transcriptional response using 12 selected putative marker genes. These genes encoded candidate biomarkers, including molecules commonly used for heavy metal biomonitoring in other species (proteins with antioxidant, detoxification or apoptosis activities) (Taylor et al., 2013; Kim et al., 2014). This targeted analysis of $P$. margaritifera identified predictive molecular biomarkers and indicators of the presence of heavy metal contamination in a coral ecosystem.

P. margaritifera $(n=150)$ from Takaroa Atoll (Tuamotu Archipelago, French Polynesia) were grown in the Vairao lagoon for 2.5 years and brought to the Ifremer laboratory in Tahiti, French Polynesia. The 
monitoring was carried out under controlled conditions for 1 month and involved 124 individuals with an average height of $82 \mathrm{~mm}$. After 1 week of acclimation, the contaminants cadmium (Cd) and chromium $(\mathrm{Cr})$ were introduced at the same time as the feeding of oysters, using for each metal a low and a high concentration (1 $1 \mu \mathrm{g} \mathrm{L}^{-1}$ and $10 \mu \mathrm{g} \mathrm{\textrm {L } ^ { - 1 }}$ ) (table 1). The control tank consisted in oysters with no heavy metal contaminants. After a decontamination phase, the concentration levels of the 2 metals were measured in triplicate within oyster tissues (table 1). During the bioassay test period, the pearl oysters were fed with the microalgae Isochrysis galbana (T-Iso) and Chaetoceraos gracilis at a constant concentration of 10 cells $\mu \mathrm{L}^{-1}$ and the temperature was stabilised around $27.9 \pm 0.2^{\circ} \mathrm{C}$.

Three oysters per treatment were sampled at different times (table 2). For low concentration tanks, samples were taken at day 1, 4 and 17 after the start of contamination (D1, D4 and D17). Contamination was stopped at D17, and sampling was done at D21 and D25 during the decontamination phase. For high concentration tanks, samples were taken at day 1, 4 and 8 after the start of contamination (D1, D4 and D8). Contamination was stopped at D8, and sampling was done at D11 during the decontamination phase (Table 2). For each harvested oyster, a fragment of the gill was sampled and subsequently stored at $-80^{\circ} \mathrm{C}$ for measuring transcriptional response to exposure, while the remaining tissue was used to quantify heavy metal concentrations accumulated in the tissues during exposure. Dead oysters were removed daily from the tanks.

Cadmium $\mathrm{CdCl}_{2}$ (cadmium chloride anhydrous, CAS 10108-64-2, Alfa Aesar) and chromium $\mathrm{CrO}_{3}$ (chromium [VI] oxide, CAS: 1333-82-0, Sigma-Aldrich) were used for conducting the heavy metal toxicity studies. The two heavy metals, cadmium (Cd) and chromium $(\mathrm{Cr})$, were quantified in soft tissue through atomic absorption spectrometry with flame (Usero et al., 2005; Izagirre et al., 2014). A calibration range was prepared for each heavy metal. Metal dissolution was performed in sea water. For each metal ( $\mathrm{Cd}$ and $\mathrm{Cr}$ ), the salts were placed in seawater for 24 hours, and the solutions were then filtered to remove undissolved residue. Previously calibrated filters were dried and weighed after filtration to obtain the mass balance of the two phases: particulate and dissolved. Each collected oyster that had previously been drained and weighed to measure fresh weight was frozen 
for $24 \mathrm{~h}$ and then freeze-dried and milled. After mineralization at $550^{\circ} \mathrm{C}$, the oyster tissues were digested in a mixture of concentrated acid $\left(\mathrm{HNO}_{3}\right.$ and $\left.5 \% \mathrm{HCl}\right)$. The heavy metal concentration was analysed following complete digestion.

Regarding the transcriptional response of oysters to heavy metal exposure, the target genes were selected based on a literature study and existing molecular data for the $P$. margaritifera pearl oyster (Joubert et al., 2010; Marie et al., 2012). The selected candidate genes were as follows: Cu/Zn superoxide dismutase (Pmarg-SOD), metallothionein (Pmarg-MT), cytochrome c oxidase (PmargCytC), caspase (Pmarg-Casp), heat-shock proteins (Pmarg-HSP70, Pmarg-HSP90), catalase (PmargCAT), glutathione peroxidase (Pmarg-GPX), multidrug resistance protein (Pmarg-MDR), inhibitor of apoptosis (Pmarg-IAp), glutathioneS-transferase omega class (Pmarg-GSTO) and Mu-class (PmargGSTM). The real-time qRT-PCR primer sequences of each target gene were designed using Primer3 software (Table 3). The primers were synthesised by Eurogentec (www.eurogentec.com).

Gill tissues of three oysters per treatment,sampled at the different time points of the analysis (identified above) were used for qPCR analysis. Total cellular RNA was extracted using TRIZOL ${ }^{\circledR}$ Reagent (Life Technologies) according to the manufacturer's recommendations. After precipitation with sodium acetate, the RNA was treated with DNase I (DNA-free KitT MDNase Treatment and Removal Reagents, Ambion), and the RNA integrity was assessed on a 1\% agarose gel. The RNA was quantified using a NanoDrop ${ }^{\circledR}$ ND-1000 spectrophotometer (NanoDrop ${ }^{\circledR}$ Technologies, Inc). The gene expression levels were analysed with quantitative RT-PCR analysis using a set of forward and reverse primers (see description above, table 3). A universal set of primers for the $18 \mathrm{~S}$ rRNA gene was used as a primary reference gene; these were designed based on the 18S rRNA sequence alignment of different bivalve species (Uni1304F: TTAGTTGGTGGAGCGATTT; Uni1670R: TAGCGACGGGCGGTGTG). A second reference gene was chosen based on its ubiquitous and constitutive expression pattern in P. margaritifera tissue (REF1S: AGCCTAGTGTGGGGGTTGG; EF1AS: ACAGCGATGTACCCATTTCC). First-strand CDNA was synthesised from $800 \mathrm{ng}$ total RNA using the Transcriptor First-Strand cDNA Synthesis Kit (Roche) and a mix of poly(dT)and random hexamer 
primers. The qPCR amplifications were carried out on a StratageneMX3000P, using Brilliant II SYBR ${ }^{\circledR}$ Green QPCR Master Mix (Stratagene) with $400 \mathrm{nM}$ of each primer and a $1 \mu \mathrm{L}$ cDNA template. The following protocol was used: initial denaturation at $95^{\circ} \mathrm{C}$ for $10 \mathrm{~min}$, followed by 40 cycles of denaturation at $95^{\circ} \mathrm{C}$ for $30 \mathrm{~s}$, annealing at $60^{\circ} \mathrm{C}$ for $1 \mathrm{~min}$ and extension at $72^{\circ} \mathrm{C}$ for $30 \mathrm{~s}$. Finally, the amplicon melting temperature curve was analysed using a melting curve program: $45-95^{\circ} \mathrm{C}$ with a heating rate of $0.1^{\circ} \mathrm{C} \mathrm{s}^{-1}$ and continuous fluorescence measurements. All measurements were performed in duplicates. The comparative Ct (threshold cycle) method was used to analyse expression levels of the genes of interest. All analyses were based on the $\mathrm{Ct}$ values of the PCR products. The relative expression ratio of each analysed cDNA was calculated based on the deltadelta method, normalised by the two reference genes for comparing the relative expression results, which is defined as follows: ratio $=2^{-[\Delta C t \text { sample- } \Delta C t \text { calibrator }]}=2^{-\Delta \Delta C t}$ (Livak\&Schmittgen, 2000). Here, the $\Delta \mathrm{Ct}$ calibrator of each gene is the $\Delta \mathrm{Ct}$ value mean of each gene.

The $\mathrm{Cd}$ and $\mathrm{Cr}$ concentrations in pearl oysters during the experiment were compared with the concentrations in pearl oysters at TO using Dunnett's test. Mortality was analyzed with the Probit method to determine the dose to reach $50 \%$ mortality. The expression values of the 12 candidate genes were compared using two-way ANOVAs after normalisation with the Box-Cox transformation to meet the condition for parametric ANOVAs (Shapiro-Wilk and Bartlett tests). Two-way ANOVAs were done to determine the effect of metal on gene expression compared to the control condition, the changes of gene expression during time exposure and the 'metal $x$ time' interaction. Post hoc comparison was done using Tukey's post hoc test.

Following the exposure of $P$. margaritifera pearl oysters to high $\mathrm{Cd}$ and $\mathrm{Cr}$ heavy metal concentrations $\left(10 \mu \mathrm{g} \mathrm{L}^{-1}\right)$, the cumulative mortalities were $42.8 \%$ at the end of the contamination step on D7 (figure 1). Mortality significantly increased during the decontamination step, reaching 62\%. At low concentrations $\left(1 \mu \mathrm{g} \mathrm{L}^{-1}\right)$, cumulative mortality reached $36 \%$ on D17 at the end of the contamination phase, and mortality increased by only $6 \%$ by D25 (figure 1). Finally, mortality affecting control oysters reached $10 \%$ at the end of the experiment on D25. Mortality appears to be 
independent of the concentration of $\mathrm{Cr}$. However, the concentrations of $\mathrm{Cd}$ accumulated in the pearl oysters reached 59 and $108 \mu \mathrm{g} \mathrm{kg}^{-1} \mathrm{dw}$ at the mortality threshold of $50 \%$ for the 2 metal tested concentrations 1 and $10 \mu \mathrm{g} \mathrm{L}^{-1}$, respectively (table 4).

The concentrations of contaminant were measured using total soft tissue of pearl oysters on three oysters per treatment. In the control, the Cd concentration in pearl oysters was between 3.19 and $10.85 \mathrm{mg} \mathrm{kg}^{-1}$ dry weight throughout the experiment. No significant variation in these concentrations was observed over time (figure 2a). In the contaminated tanks, in which we expected accumulation od Cd in pearl oysters tissues, the mean concentrations ranged from 10 (control value) to $60 \mathrm{mg} \mathrm{kg}^{-1}$ dry weight after 17 days of contamination for the $1 \mu g \mathrm{~L}^{-1}$ contamination treatment (figure 2a). For the $10 \mu \mathrm{gL}^{-1}$ contamination treatment, the mean accumulated concentrations were between 18 and $85 \mathrm{mg} \mathrm{kg}^{-1}$ dry weight after 7 days of contamination (figure 2a). The contact time was thus long enough to observe the accumulation of $\mathrm{Cd}$ in the animal tissue. The cessation of the daily addition of metals (D17 and D8 for the $1 \mathrm{\mu gL}^{-1}$ and the $10 \mathrm{\mu gL}^{-1}$ contamination treatments, respectively) coincided with the end of the increase in the concentration of $\mathrm{Cd}$ in the oyster tissues. However, no subsequent decrease in the heavy metal concentration in pearl oyster tissue was observed, showing that decontamination takes much longer than contamination.

There was no accumulation of $\mathrm{Cr}$ in pearl oyster tissues during the contamination (figure $2 \mathrm{~b}$ ). Indeed, throughout the experiment, the measured concentration of $\mathrm{Cr}$ was less than $10 \mathrm{mg} \mathrm{kg}^{-1}$ of dry weight, and no significant difference between control and contaminated oysters was observed.

The analysis of transcriptional response of pearl oysters to heavy metal contaminationrevealed two categories of genes: those whose expression was independent of the contamination with heavy metals and those that significantly changed after contamination by heavy metals.

At the dose of $1 \mathrm{\mu g} \mathrm{L}^{-1}$, only three of the twelve tested genes showed a significant change in relative expression as a result of exposure to heavy metals (table 5, figure 3). These were the MT, HSP90 and CAT genes. The MT gene expression was significantly up-regulated during both the contamination phase and the decontamination phase. The over-expression of HSP90 appeared later on, during the 
decontamination phase. The CAT gene was significantly under-regulated with the exposure to heavy metals (figure 3). The expression of three genes varies significantly under the effect of the interaction between metal and the duration of exposure. Those are the SOD, GSTO and HSP70 genes. This interaction may be due to a sub-expression during the phase of contamination and a recovery of the expression at the end phase of decontamination for the SOD gene. This interaction has a bigger impact on the expression of the HSP70 gene. The expression of the gene GSTO transiently decreased to the D4 phase of contamination and became similar to that of the control when reaching the end of the decontamination phase at D17 (figure 3).

At the dose of $10 \mu \mathrm{g} \mathrm{L}^{-1}$ (table 5, figure 4), the expression of eight genes was affected by the contamination with heavy metals. Those genes were SOD, metal, GSTO, CAT, MDR, GPX, PSAPS and GSTM. They however show different responses: SOD, GPX, PSAP, GSTM were significantly overexpressed only during the contamination phase, GPX was significantly over-expressed only in the decontamination phase, GSTO, CAT, IAp1 were under-expressed in both the contamination and decontamination phases, while MT was significantlyover-expressed in both the contamination and decontamination phases (figure 4).

The relationship between the $\mathrm{Cd}$ content in the pearl oysters tissues and the average relative expression of the gene coding for MT is a non-linear regression equation as follows:

$$
M T=3.03 \times \ln (C d)-4.844
$$

The correlation between modeled and measured values of the expression of MT in relation to the Cd content in tissues is highly significant $(r=0.890)$. This non-linear regression includes a phase where the expression of MT increases with the amount of $\mathrm{Cd}$ accumulated in tissues between 0 and $25 \mathrm{mg}$ $\mathrm{Cd}_{\mathrm{E}}-\mathrm{kg}^{-1}-\mathrm{dw}$, followed by a phase where the expression of MT reaches its maximum regardless of the Cd content accumulated in tissues (figure 5).

The heavy metal concentrations used in the experiment were within the dose range previously cited in the literature for laboratory metal exposure experiments (Thompson et al., 2011; Taylor et al., 2013; Kim et al., 2014) and are also_comparable to those observed in some heavily polluted marine 
environments (Giarratano et al., 2010; Taylor et al., 2013; Chakraborty et al., 2014). In our study, mortality was positively correlated with increasing concentrations of metals as well as increasing exposure periods. Indeed, the cumulative mortality during the exposure period showed that half of the contaminated pearl oysters died at D9 and D22 at high and low $\mathrm{Cd}-\mathrm{Cr}$ concentrations, respectively. Similar reports on the mortality of marine mollusks such as oysters, mussels, snails and clams were observed in relation to heavy metal toxicity (Sommanee, 1980; Maclnnes and Calabrese, 1978; Eisler et al., 1977). Using concentrations a thousand times higher, the lethal time $50 \%$ occurs between 1 and 3 days in Perna viridis, Modiulus carvahloi and Donax speculum exposed to Cd (Mohan et al., 1984).

In the present study, the $\mathrm{Cd}$ concentration in the control group of pearl oysters was of a $7.8 \mathrm{mg} \mathrm{kg}^{-1}$ dry weight throughout the experiment, which was within the range of those previously observed for Mytilus edulis or M. galloprovenciallis mussels and Crassostrea gigas oysters exposed in the natural environment (Giarratano et al., 2010; Maanan, 2008; Sidoumou et al., 2005). The Cr mean concentration in the control group of pearl oysters was of a $3.04 \mathrm{mg} \mathrm{kg}^{-1}$ dry weight in the range of 1.68-5.44 $\mathrm{mg} \mathrm{kg}^{-1}$ dry weight. The concentration scale found in this investigation is within the ranges found in many other bivalves (Eisler, 1981; Nicolaidou, 1994; Conti and Cechetti, 2003; Tapia et al., 2010).

In the contaminated tanks, pearl oysters accumulated $\mathrm{Cd}$ but not $\mathrm{Cr}$. The contact time was long enough to observe the accumulation of $C d$ in the animal tissue, which reached 59 and $108 \mathrm{mg} \mathrm{kg}^{-1} \mathrm{dw}$ at the threshold of $50 \%$ mortality at 1 and $10 \mu \mathrm{L} \mathrm{L}^{-1}$, respectively. A similar degree of $\mathrm{Cd}$ accumulation in P. margaritifera was also observed following experimental contamination of M. galloprovenciallis mussels (Izagirre et al., 2014). The cessation of the daily addition of metals coincided with the end of the increase in the concentration of $\mathrm{Cd}$ in the oyster tissues. However, no subsequent decrease in the heavy metal concentration in pearl oyster tissues was observed, indicating that decontamination takes much longer than contamination. This is strong support for the use of $P$. margaritifera as a sentinel species, since Cd contamination shows long-term retention and detectability in the gills. 
There was no accumulation of $\mathrm{Cr}$ in the pearl oyster tissues during the contamination. These results differ from those of Medina et al. (1986), who observed a high concentration of $\mathrm{Cr}$ in bivalves from the Mediterranean Sea. However, apart from the measured traces of $\mathrm{Cr}$ in the environment, few contamination experiments with $\mathrm{Cr}$ have been performed with bivalves. A similar experiment showed a significant accumulation of $\mathrm{Cr}$ in mussel gills after $96 \mathrm{~h}$ treatment with 0.1 and $1 \mathrm{\mu gL}^{-1} \mathrm{Cr}$ (Ciacci et al., 2012). These different results might be explained by the experimental conditions or the form of $\mathrm{Cr}$ used, or by the limit of sensitivity of the detection method, but they may also emphasise that $\mathrm{Cr}$ is poorly retained by pearl oysters.

Cd ions entering cells are transported to target tissues and are incorporated through a molecular and ionic mechanism, substituting the proper ions in their metabolic sites (Bridges and Zalups, 2005). In the different tissues or cells, Cd selectively focuses on a number of molecules, such as MT, which ensure its detoxification. As a result, $\mathrm{Cd}$ is in competition with other metals (zinc, copper). Exposure to $\mathrm{Cd}$ may also stimulate the production of MTs; indeed, recent studies have shown that $\mathrm{Cd}$ can accumulate in aquatic invertebrates, causing a rise in the intracellular level of MT (Amiard et al., 2006; Ma et al., 2008, 2009). In the present study, the expression of the gene coding for MT has been strongly stimulated following $\mathrm{Cd}$ exposure, and as in other taxa such as fish, the response is as strong with $1 \mu \mathrm{g} \mathrm{L}^{-1}$ as with $10 \mu \mathrm{gL}^{-1}$ (Espinoza et al., 2012). Cd accumulation is correlated to MT protein accumulation in the gills and mantle of mussels (Li et al., 2015). The up-regulation of MT in $P$. margaritifera persists at least 8 days after the cessation of the contamination at the low $\mathrm{Cd}$ concentration, due to the persistence of cadmium accumulated in the flesh. An important result of this study is $\mathrm{h}$ the establishment of the relationship between $\mathrm{Cd}$ accumulated in tissue and the relative MT expression. This could also suggest that the detoxification capacity is limited as soon as the $\mathrm{Cd}$ content accumulated in the tissues exceeds the $25 \mathrm{mg} \cdot \mathrm{kg}^{-1} \mathrm{dw}$, and that beyond this level of contamination, mortality occurs.

Cadmium (Cd) is known to influence the oxidative status of marine organisms and can induce the formation of reactive oxygen species (ROS). Lipid peroxidation by ROS is considered to be a major 
mechanism by which oxyradicals can cause tissue damage, leading to impaired cellular function and alteration in physicochemical properties of cell membranes (Vlahogianni and Valavanidis, 2007). It has been reported that $\mathrm{Cd}$ affects the functioning of antioxidant enzymes such as CAT and SOD (Wang et al., 2013), but there is a degree of transcriptional regulation in an attempt to neutralise the effects of Cd on enzyme activity by increasing the level of expression of the SOD and CAT genes, as found in the octopus (Nicosia et al., 2015). This compensation mechanism does not seem to be present in $P$. margaritifera because the SOD and CAT genes are strongly down-regulated under exposure to $\mathrm{Cd}$, reducing the corresponding enzymes' synthesis capability. In addition to the antioxidant enzymatic system that represents the SOD and CAT genes, exposure of $P$. margaritifera to a $\mathrm{Cd}$ dose of $10 \mu \mathrm{g} \mathrm{L}^{-1}$ caused a negative response of a non-enzymatic system represented by GPX, GSTO and GSTM genes. The literature describes the effect of low concentrations of cadmium, which increase the GSH concentration in cells (Pathak and Khandelwal, 2006), allowing the cell to implement defense mechanisms. Indeed, although the exposure of P.margaritifera to a low dose of Cd has not disrupted the GPX and GST systems, the high concentrations of toxic substances did repress antioxidant systems, and which led to under-expression of GPX, GSTO and GSTM..

Heat shock proteins are involved in protection against a wide range of environmental stressors, and their expression is triggered by the presence denatured/misfolded proteins in the cell. Cytosolic HSP70 and HSP90 are among the most abundant cellular proteins protecting against stress-induced damage (Mayer and Bukau, 2005). Most commonly, HSP70 expression in bivalve molluscs is upregulated during exposure to low concentrations of metals, whereas that of HSP9O is unchanged (Taylor et al., 2013). However, Werner and Hinton (1999) found that the expression of HSP70 and HSP90 was down-regulated in contaminated field sites compared to controls. They hypothesized that this might be due to the disruption of the protein synthesis in highly contaminated environments. Thompson et al. (2011) also found a reduced level of HSP70 protein expression in response to $\mathrm{Cd}, \mathrm{Pb}$ and $\mathrm{Zn}$, whereas no significant difference in the expression of HSP9O was observed. The response pattern expressed by P. margaritifera to contamination by Cd seemed atypical for the HSP. Indeed, 
an up-regulation of HSP70 and HSP90 were observed only one day after the contamination at high concentrations of $\mathrm{Cd}\left(10 \mu \mathrm{g} \mathrm{L}{ }^{-1}\right)$, but did not persist through time, which could be sufficient to protect cells with cellular repair mechanisms. The detoxification genes represented by the multidrug resistance protein (MDR1), cytochrome c oxydase (CytC), and inhibitor of apoptosis (IAp1), a gene involved in the synthesis of proteins associated with apoptosis, showed negatively modified expressions. Like the caspase (CASP) which is down-regulation with high Cd levels, this downregulation could correspond to a weakening of the anti-inflammatory response (Mcllwain et al., 2013), and thus be independent of apoptosis (Lemarie et al., 2004, Shih et al., 2004).

This study demonstrates that exposure to Cd elicits significant changes in the transcription patterns of putative biomarker genes in P. margaritifera. Among the twelve candidate genes potentially involved in the response of the pearl oyster to heavy metal contamination, eight could be considered candidate biomarkers of a heavy metal contamination in the environment. Two of them, MT and CAT, showed a high sensitivity to $\mathrm{Cd}$ exposure, even at low doses, (respectively up-regulated and down-regulated).. MT and CAT genes could be relevant biomarkers for 3 reasons: (1) their sensitivity to low dose of metal, (2) their progressive response to the metal concentration and (3) their ability to conserve their modified expression pattern in tissues during the phase of decontamination. They would thus allow detection of low levels of contamination, as well as transient contaminations. The others genes (SOD, GSTO, GPX, CASP, GSTM, MDR) were all down-regulated at high metal concentration during exposure time, therefore they could be used in case of high ongoing contamination. Further studies should evaluate the pearl oyster's transcriptional response in other tissues, to confirm the observed data or to highlight tissue-specific differences in expression and response to heavy metal exposure. Based on this study and on the demonstration of the sensitivity of two highly relevant biomarker genes (MT and CAT), the pearl oyster P. margaritifera could be used as a sentinel species for monitoring the health of the Polynesian lagoon ecosystem. Such a surveillance network could be easily implemented at the scale of French Polynesia, since pearl oysters are already present in most of the populated islands of French Polynesia. 


\section{Acknowledgement}

This study was financially supported by ANR funding: Labex CORAIL (ANR-10-LABX-08), POLYPERL project (ANR-11-AGRO-006-01-POLYPERL) and "State-country project contract" (agreement n'299 12 $-17 / 10 / 2012)$.

\section{References}

Amiard J-C., Amiard-Triquet C., Barka S., Pellerin J., Rainbow P.S. ,2006. Metallothioneins in aquatic invertebrates: Their role in metal detoxification and their use as biomarkers. AquatToxicol 76: 160202. PMID: 16289342

Bridges C.C. and Zalups R. K., 2005. Molecular and ionic mimicry and the transport of toxic metals, Toxicology and Applied Pharmacology 204, 274-308.

Chakraborty S., Bhattacharya T., Singh G., Maity J.P., 2014. Benthic macroalgae as biological indicators of heavy metal pollution in the marine environments: A biomonitoring approach for pollution assessment. Ecotoxicology and Environmental Safety 100, 61-68.

Ciacci C., Barmo C., Gallo G., Maisano M., Cappello T., D’Agata A., Leonzio C.,Mauceri A., Fasulo S., Canesi L., 2012.Effects of sublethal, environmentally relevant concentrations of hexavalent chromium in the gills of Mytilus galloprovincialis. AquaticToxicology 120-121, 109-118.

Conti M., Cecchetti G., 2003. A biomonitoring study: Trace metals in algae and mollucs from Tyrrenian coastal areas. Environmental Research 93, 99-112.

Eisler R., Hennekey R., 1977. Acute toxicities of $\mathrm{Cd}^{+2}, \mathrm{Cr}^{+6}, \mathrm{Hg}^{+2}, \mathrm{Ni}^{+2}$, and $\mathrm{Zn}^{+2}$ to estuarine macrofauna. Arch. Environ. Contam.Toxicol.6: 315.

Eisler R., 1981. Trace Metal Concentrations in Marine Organisms (p. 685). Oxford:Pergamon Press

Espinoza H., WilliamsC., Gallagher E.,2012.Effect of cadmium on glutathione S-transferase and metallothionein gene expression in coho salmon liver, gill and olfactory tissues. Aquatic Toxicology. 110-111, 37-44.

Fu F., Wang Q., 2011. Removal of heavy metal ions from wastewaters: a review. Journal of Environmental Management 92, 407-418.

Giarratano E., Duarte C.A., Amin O.A., 2010.Biomarkers and heavy metal bioaccumulation in mussels transplanted to coastal waters of the Beagle Channel. Ecotoxicology and Environmental Safety 73, 270-279.

Hosono T., Su C., Delinom R., Umezawa Y., Toyota T., Kaneko S., Taniguchi M., 2011.Decline in heavy metal contamination in marine sediments in Jakarta Bay, Indonesia due to increasing environmental regulations. Estuarine Coastal and Shelf Science 92, 297-306.

Izagirre U., Errasti A., Bilbao E., Múgica M., Marigómez I., 2014.Combined effects of thermal stress and $\mathrm{Cd}$ on lysosomal biomarkers and transcription of genes encoding lysosomal enzymes and HSP70 in mussels, Mytilus galloprovincialis.AquaticToxicology149, 145-156.

Joubert C., Piquemal D., Marie B., Manchon L., Pierrat F., Zanella-Cleon I., Cochennec-Laureau N., Gueguen Y., Montagnani C., 2010.Transcriptome and proteome analysis of Pinctada margaritifera calcifying mantle and shell: focus on biomineralization. BMC Genomics 11, 613-626. 
Kim S.H., Kim S.J., Lee J.S., Lee Y.M., 2014. Acute effects of heavy metals on the expression of glutathione-related antioxidant genes in the marine ciliate Euplotes crassus. Marine Pollution Bulletin $85,455-462$.

Lemarié A., Lagadic-Gossmann D., Morzadec C., Allain N., Fardel O., Vernhet L. 2004. Cadmium induces caspase-independent apoptosis in liver Hep3B cells: role for calcium in signaling oxidative stress-related impairment of mitochondria and relocation of endonuclease $G$ and apoptosis-inducing factor. Free Radical Biology and Medicine 36, 1517-1531.

Li Y., Yang H., Liu N., Luo J., Wang Q., Wang L. 2015.Cadmium Accumulation and Metallothionein Biosynthesis in Cadmium-Treated Freshwater Mussel Anodonta woodiana. PLoS ONE 10(2): 0117037. doi:10.1371/journal.pone.0117037.

Livak K.J., Schmittgen T.D., 2001. Analysis of relative gene expression data using real-time quantitative PCR and the 2(-Delta DeltaC(T)) method. Methods 25, 402-408.

Ma W.L., Wang L., He Y.J., Yan T., 2008.Tissue-specific cadmium and metallothionein levels in freshwater crab Sinopotamonhenanense during acute exposure to waterborne cadmium. Environ Toxicol 23, 393-400. doi: 10.1002/tox.20339 PMID: 18214890.

Ma W.L., Yan T., He Y.J., Wang L., 2009.Purification and cDNA Cloning of a Cadmium-Binding Metallothionein from the Freshwater Crab Sinopotamonhenanense. Arch Environ ContamToxicol 56, 747-753. doi: 10.1007/s00244-008-9224-4 PMID: 18846314.

Maanan M., 2008. Heavy metal concentrations in marine molluscs from the Moroccan coastal region. Environmental Pollution 153, 176-183.

Mcllwain D.R., Berger T., Mak T.W.,2013.Caspase functions in cell death and disease. Cold Spring HarbPerspectBiol. 5.a008656.

Mc Innes J.R., Calabrese A., 1978. Response of embryos of the American oyster, to heavy metals at different temperatures. In : Physiology and Behaviour of Marine Organisms, edited by D.S. Lucky \& A.J. Berry (Pergamon press, New York),195-202.

Marie V., Gonzalez P., Baudrimont M., Boutet I., Moraga D., Bourdineaud J.-P.,Boudou A. (2006).Metallothionein gene expression and protein levels in triploid and diploid oysters Crassostrea gigas after exposure to cadmium and zinc. Environmental Toxicology and Chemistry 25: 412-418.

Medina J., Hernandez E., Pastor A., Beferull J.B., Barbera J.C., 1986. Determination of mercury, cadmium, chromium and lead in marine organisms by flameless atomic absorption spectrophotometry. Marine Pollution Bulletin 17, 41-44.

Mohan C.V., MenonN.R., Gupta T.R.C.,1984. Acute toxicity of Cadmium to six intertidal invertebrates. Fishery Technology 21, 1-5.

Moore M.N., Depledge M.H., Readmen J.W., Leonard D.R.P., 2004. An integrated biomarker-based strategy for ecotoxicological evaluation of risk in environmental management. Mutation Research $552,247-268$.

Naser H.A. 2013. Assessment and management of heavy metal pollution in the marine environment of the Arabian Gulf: A review. Marine Pollution Bulletin 72, 6-13. 
Nicolaidou A. 1994.Identification of biological indicators of heavy metals at the site of a smelting factory. UNEP/FAO, final reports on research projects dealing with the effect of pollutants on marine organisms and communities. MAPtechnical reports series $\mathrm{N}^{\circ} 80,25-38$, Athe.

Nicosia A., Salamone M., Mazzola S., Cuttitta A. 2015. Transcriptional and biochemical effects of cadmium and manganese on the defense system of Octopus vulgaris paralarvae. BioMed Research International, article ID 437328, 11 p. http://dx.doi.org/10.1155/2015/437328.

Pathak N., Khandelwal S., 2006. Oxidative stress and apoptotic changes in murine splenocytes exposed to cadmium. Toxicology 220, 26-36.

Salvat B., Aubanel A., Adjeroud M., Bouisset P., Calmet D., Chancerelle Y., Cochennec N., Davies N., Fougerousse A., Galzin R., Lagouy E., Lo C., Monier C., Ponsonnet C., Remoissenet G., Schneider D., Stein A., Tatarata M., Villiers. L., 2008. Le suivi de l'état des récifs coralliens de Polynésie française et leur récente évolution. Revue d'Ecologie (Terre Vie) 63, 103-135.

Shih C.-M., Ko W.-C., Wu J.-S., Wei Y.-H., Wang L.-F., Chang E.-E., Lo T.-Y., Cheng H.-H.,Chen C.T.,2004.Mediating of caspase-independent apoptosis by cadmium through the mitochondria-ROS pathway in MRC-5 fibroblasts. J. Cell. Biochem. 91, 384-397. doi:10.1002/jcb.10761.

Sidoumou Z., Gnassia-Barelli M., Siau Y., Morton V., Roméo M., 2005.Heavy metal concentrations in molluscs from the Senegal coast. Environment International 32, 384-387.

Sommanee P. (1980).Toxicity of heavy metals on Donaxfaba Chemnitz.Thai. Fish Gazette 32, 391-402.

Taylor D.A., Thompson E.L., Nair S.V., Raftos D.A., 2013. Differential effects of metal contamination on the transcript expression of immune and stress-response genes in the Sydney Rock oyster, Saccostreaglomerata. Environmental Pollution 178, 65-71.

Tiapa J., Vargas-Chacoff L., Bertrán C., Carrasco G., Torres F., Pinto R.,Urzúa S.,Valderrama A., Letelier L., 2010. Study of the content of cadmium, chromium and lead in bivalve molluscs of the Pacific Ocean (Maule Region, Chile). Food chemistry 121, 666-671.

Thompson E.L., Taylor D.A., Nair S.V., Birch G., Haynes P.A., Raftos D.A., 2011. A proteomic analysis of the effects of metal contamination on Sydney Rock Oyster (Saccostreaglomerata) haemolymph. Aquatic Toxicology 103, 241-249.

Usero J., Morillo J., Gracia I., 2005. Heavy metal concentrations in molluscs from the Atlantic coast of southern Spain. Chemosphere 59, 1175-1181.

Viarengo A., Lowe D., Bolognesi C., Fabbri E., Koehler A., 2007. The use of biomarkers in biomonitoring: A 2-tier approach assessing the level of pollutant-induced stress syndrome in sentinel organisms. Comparative Biochemistry and Physiology Part C 146, 281-300.

Vlahogianni T.H., Valavanidis A.,2007. Heavy-metal effects on lipid peroxidation and antioxidant defense enzymes in mussels Mytilus galloprovincialis. Chem. Ecol. 23,361-371.

Wang J., Zhang P., Shen Q., Wang Q., Liu D., Li J., Wang L.,2013. The Effects of Cadmium Exposure on the Oxidative State and Cell Death in the Gill of Freshwater Crab Sinopotamonhenanense. PLOS ONE 8(5): e64020. doi:10.1371/journal.pone.0064020. 
Table 1: Experimental design.

\begin{tabular}{cccccc}
\hline & $\begin{array}{c}\text { Cadmium } \\
\mu \mathrm{g} \mathrm{L}^{-1}\end{array}$ & $\begin{array}{c}\text { Chromium } \\
\mu \mathrm{g} \mathrm{L}^{-1}\end{array}$ & $\begin{array}{c}\text { Pearl oyster } \\
\text { number } / \text { tank }\end{array}$ & Replicate tank & $\begin{array}{c}\text { Total number of } \\
\text { pearl oyster }\end{array}$ \\
\hline High & $10.22 \pm 0.11$ & $11.47 \pm 1.64$ & 15 & 3 & 45 \\
Low & $1.02 \pm 0.001$ & $1.15 \pm 0.13$ & 15 & 3 & 45 \\
Control & 0 & 0 & 17 & 2 & 34 \\
\hline
\end{tabular}

Table 2: Sampling protocol: number of pearl oyster sampled according to the exposition level and duration. Numbers in bold indicatethat the pearl oysters were in the decontamination step.

\begin{tabular}{ccccccccc}
\hline & D1 & D4 & D8 & D11 & D17 & D21 & D25 & Total sampling \\
\hline High & 3 & 3 & 3 & 3 & & & & 12 \\
Low & 3 & 3 & & & 3 & $\mathbf{3}$ & $\mathbf{3}$ & 15 \\
Control & 3 & 3 & 3 & 3 & 3 & 3 & 3 & 21 \\
\hline
\end{tabular}

Table 3: Primer sequences for qRT-PCR. Cu/Zn superoxide dismutase (Pmarg-SOD), metallothionein (Pmarg-Metal), cytochrome C oxydase (Pmarg-CytC), caspase (Pmarg- Casp), heat-shockproteins (PmargHSP70, Pmarg-HSP90), catalase (Pmarg-Cat), glutathione peroxidase (Pmarg-GPX), multi-drug resistance protein (Pmarg-MDR1), inhibitor of apoptosis (Pmarg-IAp1), glutathione S-transferase omega class (Pmarg-GSTO) and mu-class (Pmarg-GSTM).

\begin{tabular}{lll}
\hline Gene name & Forward primer $\left(\mathbf{5}^{\prime}\right.$ - $\left.^{\prime} \mathbf{3}^{\prime}\right)$ & Reverse Primer $\left(\mathbf{3}^{\prime} \mathbf{}^{\prime}>\mathbf{5}^{\prime} \mathbf{)}\right.$ \\
\hline Pmarg-SOD & ATCTTGGAAATGTCACAGCAG & CATCAATATCAGCATGCACCA \\
Pmarg-Metal & CCATGTGCTTGTTCTGACTC & TACATCCTACTCCACATCCAC \\
Pmarg-CytC & GGATAGATGTAGACACTCGG & CAATGTCTAAAGAGGCGCTG \\
Pmarg-Casp & ATGGTGACAATGGAGTGGTG & TGACAGGCTTGGATAAAGAAC \\
Pmarg-HSP9 & 0 CAAGGCAGAGTTTGAAGGAC & CAGCCTGTTAGATACCACCA \\
Pmarg-HSP7 & 0 TCTGTGCCTTGTCCATCTTG & AACCCTGTCATCCAGTACAC \\
Pmarg-CAT & AGATTATGCCATCCGTGACC & TCCTGTTCAACACCATCCTG \\
Pmarg-GPX & ACTTCTACGGAATCTGACGG & GTCTCACATAGCGTAGACCA \\
Pmarg-MDR1 & AACACATAGGCTTAGTTGGTC & CAATGTCTCGTAGCCATCTG \\
Pmarg-IAp1 & ATTGAGGAATTGGGAGCCAG & GCTGACAAAGCAACATTGCC \\
Pmarg-GSTO & ACAGTATGAGGTTCTGTCCC & ATCTTTCCGTCCTTCTCCAG \\
Pmarg-GSTM & GACAAACAATATGAGCAGGGA & CCAGAAGTCCATGTTTAGCAG \\
\hline
\end{tabular}

Table 4: Metal concentration ( $\mu \mathrm{g} \mathrm{kg}^{-1} \mathrm{dw}$ ) in tissues of animals when mortality reached $50 \%$ of the population.

\begin{tabular}{ccc}
\hline Metal dose & & $\mathrm{Cd}$ \\
\hline 0 & Mean value & 7.8 \\
\hline 1 & LD 50 value & 59 \\
10 & LD 50 value & 108 \\
\hline
\end{tabular}


Table 5:ANOVA significance level of gene expression according to the metal dose and the kinetic of contamination and decontamination.

\begin{tabular}{|c|c|c|c|c|c|c|c|c|c|c|c|c|c|}
\hline & factors & SOD & Metal & GSTO & HSP90 & CAT & MDR & CytC & HSP70 & GPX & CASP & IAp1 & GSTM \\
\hline \multirow{3}{*}{$\begin{array}{l}\frac{100}{2} \\
7 \\
-1 \\
n \\
0 \\
0\end{array}$} & dose & 0.166 & 0.009 & 0.164 & 0.033 & 0.041 & 0.660 & 0.060 & 0.348 & 0.974 & 0.062 & 0.440 & 0.648 \\
\hline & time & 0.082 & 0.823 & 0.957 & 0.021 & 0.177 & 0.696 & 0.018 & 0.048 & 0.029 & 0.190 & 0.020 & 0.001 \\
\hline & interaction & 0.002 & 0.474 & 0.036 & 0.258 & 0.201 & 0.999 & 0.348 & 0.031 & 0.172 & 0.165 & 0.142 & 0.397 \\
\hline \multirow{3}{*}{$\begin{array}{l}\frac{0}{2} \\
2 \\
0 \\
\text { - } \\
\text { n } \\
0 \\
0\end{array}$} & dose & 0.005 & $<0.0001$ & 0.013 & 0.101 & $<0.0001$ & 0.025 & 0.716 & 0.274 & 0.018 & 0.001 & 0.465 & 0.028 \\
\hline & time & 0.143 & 0.048 & 0.252 & 0.638 & 0.726 & 0.349 & 0.054 & 0.765 & 0.025 & 0.375 & 0.325 & 0.002 \\
\hline & interaction & 0.083 & 0.485 & 0.150 & 0.658 & 0.268 & 0.645 & 0.088 & 0.304 & 0.009 & 0.206 & 0.911 & 0.076 \\
\hline
\end{tabular}


Figure 1: Cumulative mortality of pearl oysters during the experimental contamination by cadmium (Cd) and chromium $(\mathrm{Cr})$ in controlled conditions. Initially, each tank contained 15 pearl oysters. Contaminated tanks were in triplicate (dotted and dash lines for high and low metal contamination respectively), control tank were in duplicate (continuous line). Arrows represent the end of the contamination phase and the beginning of the decontamination phase (D8 and D17for high and low metal contamination respectively).

Figure 2: (a) Cadmium ( $C d)$ and (b) chromium ( $C r)$ concentrations in the pearl oyster $(n=3)$. The error bars represent the standard error. Dotted and dash lines are for high and low metal contamination, respectively, and continuous line for control. Arrows represent the end of the contamination phase and the beginning of the decontamination phase (D8 and D17for high and low metal contamination, respectively).Asterisks indicate the significantly different averages compare to T0 control.

Figure 3: Relative expression levels of genes encoding proteins potentially involved in the stress response to low cadmium ( $\mathrm{Cd}$ ) and chromium $(\mathrm{Cr})$ exposure in the pearl oyster $P$. margaritifera during the kinetic of contamination and decontamination. The dotted lines represent the end of the contamination phase and the beginning of the decontamination phase (D17).

Figure 4: Relative expression levels of genes encoding proteins potentially involved in the stress response to high cadmium $(\mathrm{Cd})$ and chromium $(\mathrm{Cr})$ exposure in the pearl oyster $P$. margaritifera during the kinetic of contamination and decontamination. The vertical dotted lines represent the end of the contamination phase and the beginning of the decontamination phase (D8 for the high contamination treatments).

Figure 5: Effect of cadmium (Cd) contamination in tissue on the relative expression of metallothionein (MT). Light grey rhombuses correspond to control, dark grey square to low contamination and black triangle to high contamination. 


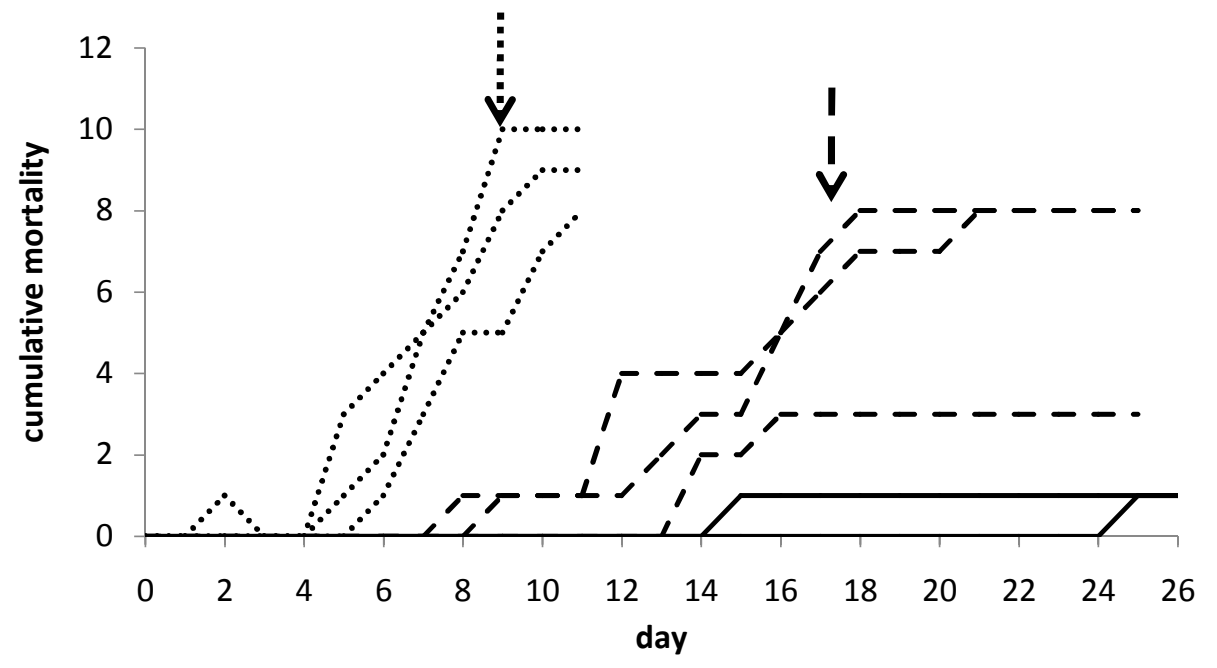

Figure 1 

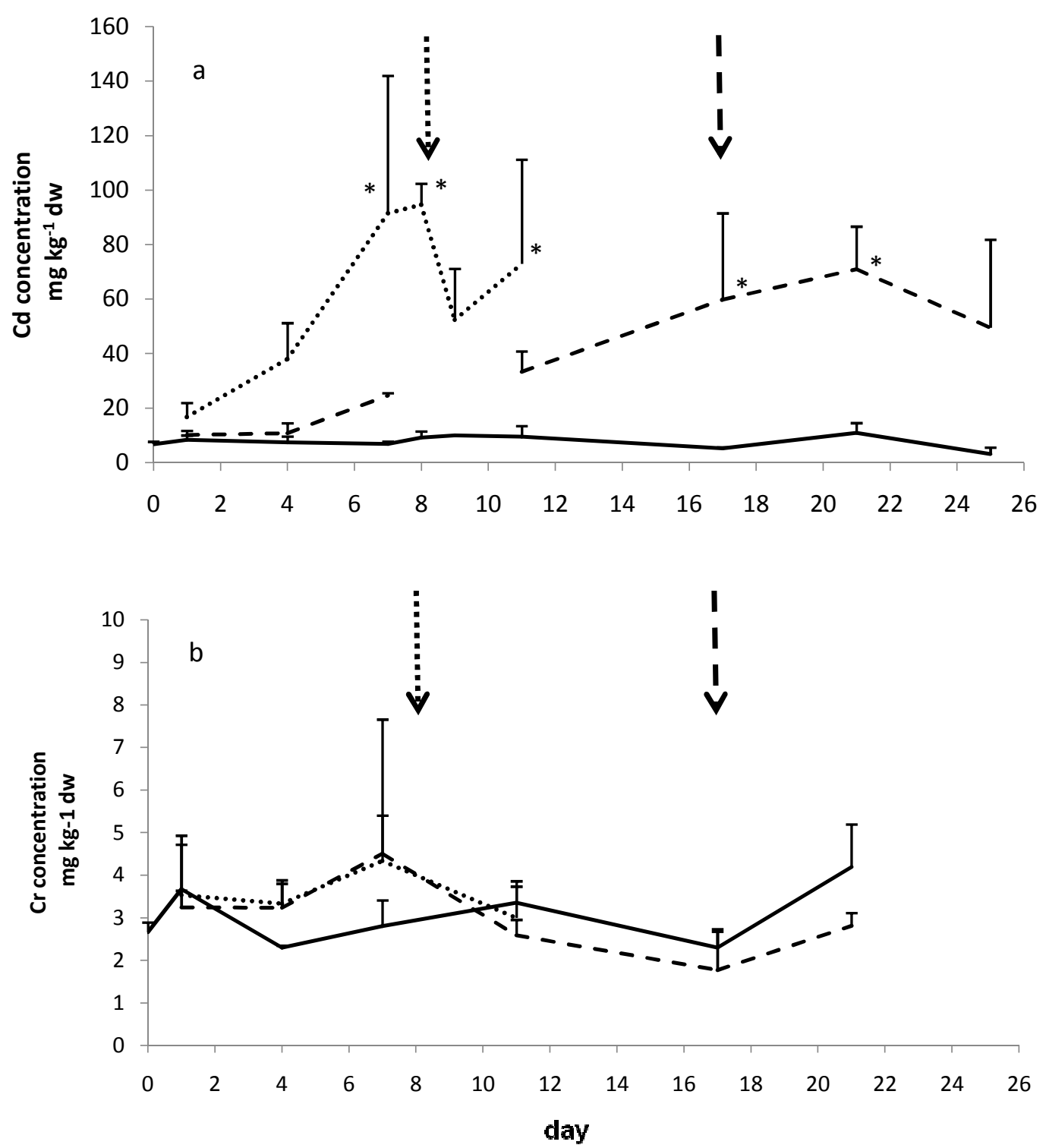

Figure 2 

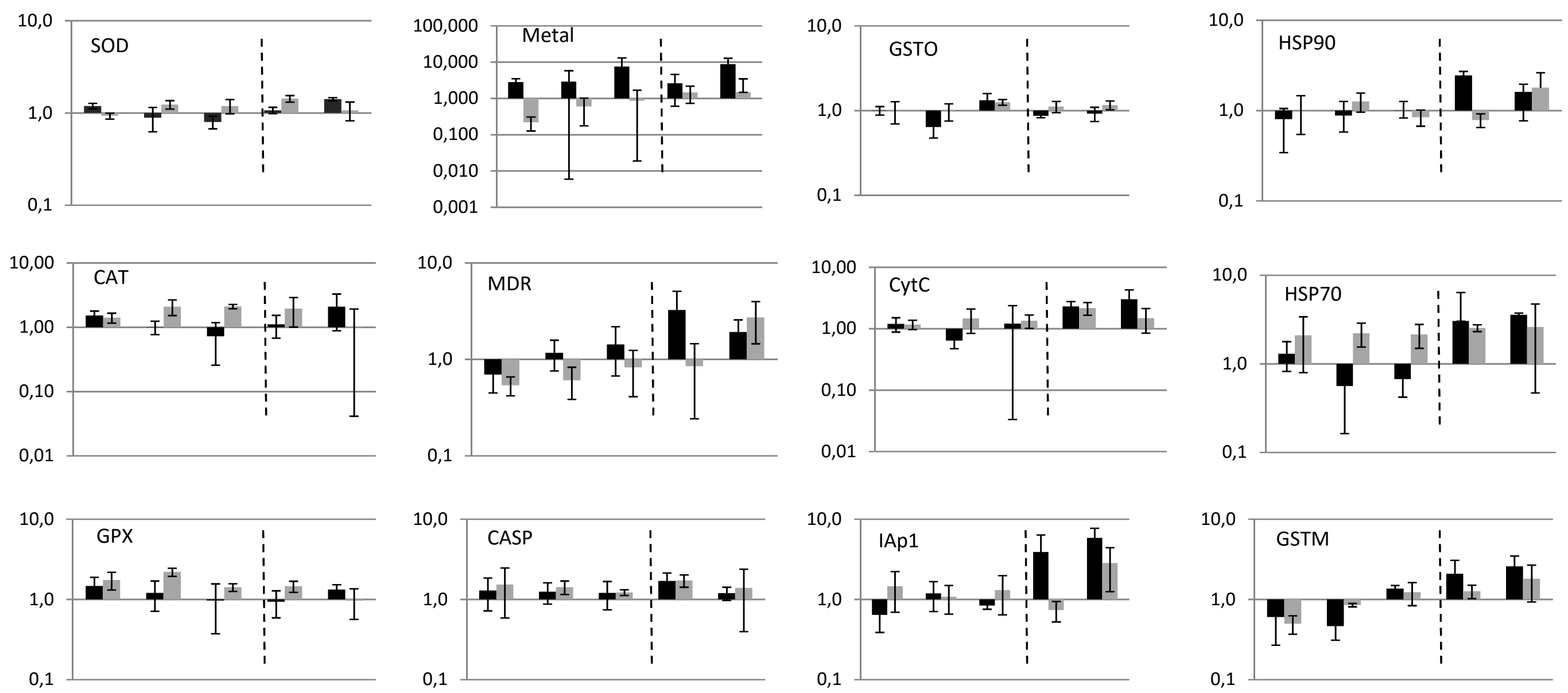

$\begin{array}{lllll}\text { D1 } & \text { D4 } & \text { D17 } & \text { D21 } & \text { D25 }\end{array}$

$\begin{array}{lllll}\text { D1 } & \text { D4 } & \text { D17 } & \text { D21 } & \text { D25 }\end{array}$

$\begin{array}{lllll}\text { D1 } & \text { D4 } & \text { D17 } & \text { D21 } & \text { D25 }\end{array}$

$\begin{array}{lllll}\text { D1 } & \text { D4 } & \text { D17 } & \text { D21 } & \text { D25 }\end{array}$ 

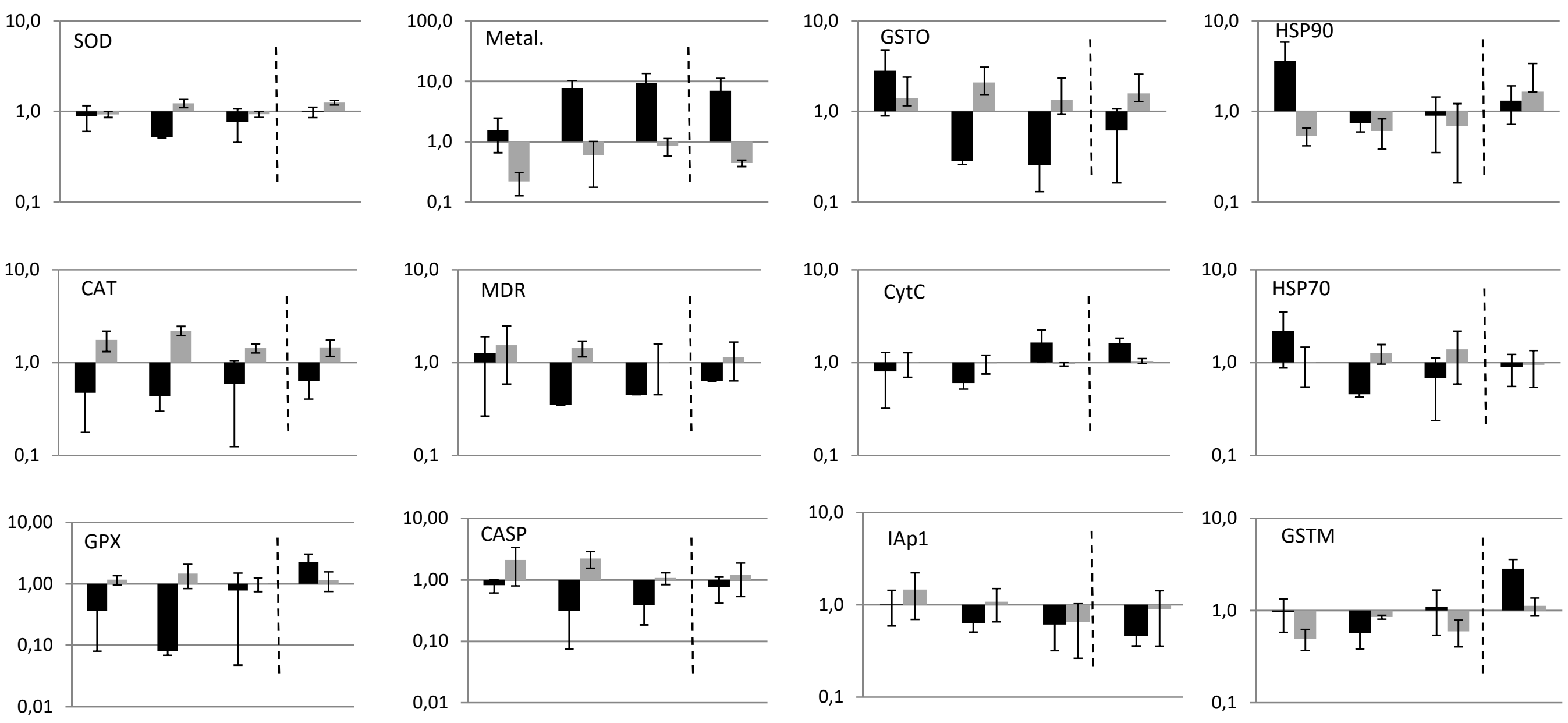

$\begin{array}{llll}\text { D1 } & \text { D4 } & \text { D8 } & \text { D11 }\end{array}$

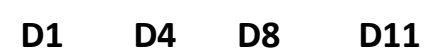

$\begin{array}{llll}\text { D1 } & \text { D4 } & \text { D8 } & \text { D11 }\end{array}$

D1 D4 D8

D11 


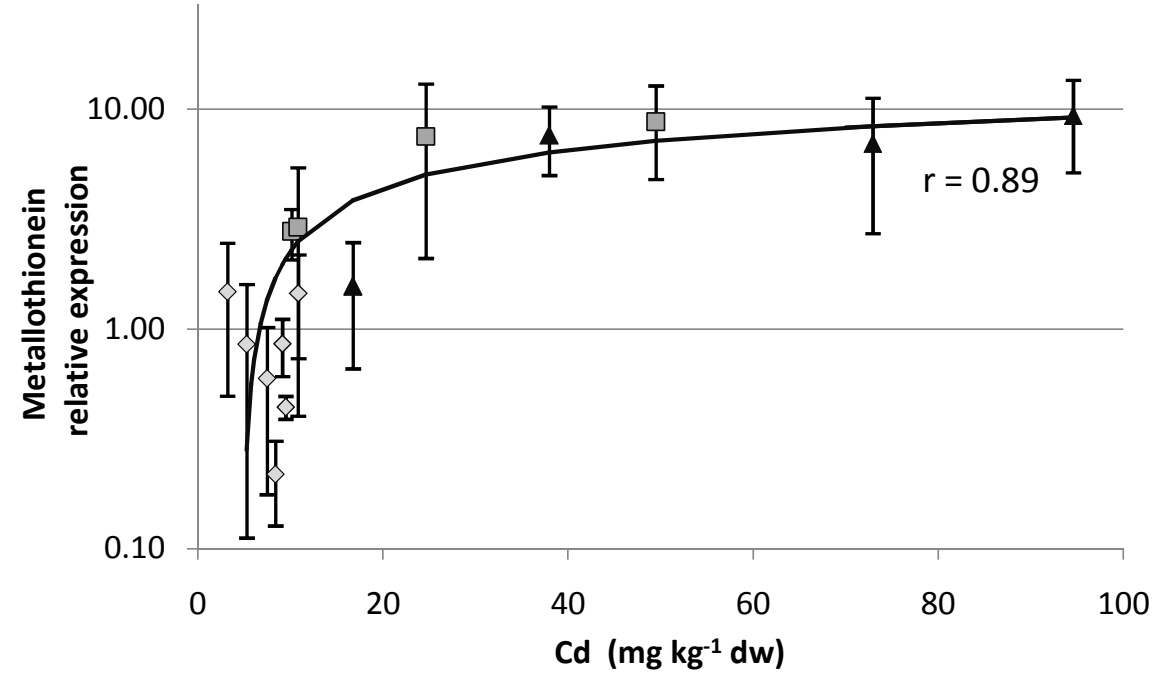

Figure 5 